\title{
Research article \\ Cytokine profile as biomarker of COVID-19 and its correlation with liver function enzymes and other markers of inflammation
}

\author{
Gita Nepal ${ }^{1}$, Maitreyee D. S. ${ }^{2}$, Akshatha Rao Aroor ${ }^{3}$, Shivashankara A. R. ${ }^{4}$ \\ ${ }^{1}$ M.Sc. MLT Student in Biochemistry, ${ }^{2}$ Associate Professor of Biochemistry, ${ }^{3}$ Associate Professor of General Medicine, \\ ${ }^{4}$ Professor of Biochemistry, Father Muller Medical College, Mangalore, Karnataka India
}

(Received: July $2021 \quad$ Revised: September $2021 \quad$ Accepted: November 2021)

Corresponding author: Shivashankara A. R. Email: sramachandrayya@fathermuller.in

\begin{abstract}
Introduction and Aim: Various hematological and biochemical parameters are assessed as biomarkers of COVID19, caused by the SARS-CoV-2. In this study, efforts were made to identify the correlation of cytokines (IL-6, TNF$\alpha$, IL-1 $\alpha$, and IL-1 $\beta$ ) with the liver function enzyme markers, LDH, CRP, Ferritin, and D-dimer. We also assessed the correlation of cytokines with severity of COVID-19.

Materials and Methods: We analyzed 53 serum samples of RT-PCR-positive patients admitted to the hospital. Cytokines (IL-6, TNF- $\alpha$, IL-1 $\alpha$, and IL-1 $\beta$ ) were analyzed with sandwich ELISA. The levels of cytokines were compared between mild, moderate, and severe cases of COVID-19, and the correlation among cytokines, liver function marker enzymes, LDH, CRP, D-dimer, and ferritin were analyzed.
\end{abstract}

Results: Along with CRP, LDH and ferritin, IL-6 showed significant difference between mild, moderate, and severe COVID groups. significant correlation between IL-6 \& LDH (p -.002), IL-6 \& D-Dimer (p- .010), IL-6 \& IL-1 (p$.027)$, IL-1 $\beta \&$ D-Dimer (p- .010), IL-1 $\beta \&$ LDH (p-.027), and IL-1 $\beta \&$ TNF- $\alpha \&$ (p-.000).

Conclusion: Cytokines especially IL-6 correlated with disease severity. Assaying the profile of cytokines could be of immense value in diagnosis, prognosis, and management of COVID-19.

Keywords: Biomarker; COVID-19; cytokines; inflammation; interleukins.

\section{INTRODUCTION}

$\mathrm{T}$ he COVID-19 is caused by the SARS-CoV-2. These positive single-stranded large RNA viruses belong to the beta-coronaviruses subfamily. COVID-19, an acute respiratory infection has become pandemic and a serious threat to the whole world since 2019, has led to millions of deaths and hospitalization worldwide (1). Along with the respiratory symptoms, various degree of liver and cardiac damages are seen in hospitalized patients $(2,3)$. COVID-19 infection shows an aggressive inflammatory response, releasing a large amount of pro-inflammatory cytokines known as "cytokine storm". Cytokines are produced by immune cells like innate macrophages, dendritic cells, natural killer cells $\mathrm{T}$ and $\mathrm{B}$ lymphocytes. The cytokine stimulates the activity of the genes which are involved in the process of inflammation and immunity, and called "proinflammatory"(4). Most important pro-inflammatory cytokines of the innate immune response are IL-1 $\alpha$, TNF- $\alpha$, and IL-6. COVID-19patients show a wide range of clinical severity from asymptomatic to fatal conditions. Advanced age, underlying comorbidities weakened immune system, cytokine release syndrome and lymphopenia are risk factors for higher severity of illness and death from COVID-19(4). Cytokine storm is a maladaptive cytokine release in response to infection and other stimuli. The pathogenesis is complex but includes loss of regulatory control of proinflammatory cytokine production, both at local and systemic levels. Evidence shows that, in COVID- 19 epidemic, severe deterioration in some patients is closely associated with dysregulated, excessive cytokine release phenomenon (5).

Several biomarkers are being used for the diagnosis of COVID-19along with the RT-PCR. Such biomarkers include, C-reactive protein (CRP), ferritin, D-dimer and lactate dehydrogenase (LDH). Ferritin and CRP not only act as an acute-phase reactants but, also is responsible for the synthesis of cytokines and causes cytokine storm(6). Some studies have suggested to have a high level of TNF- $\alpha$ in the patient with inflammatory disease and hence suggested to use antiTNF antibody in the treatment of COVID-19to hospitalized patients to prevent the progression of the disease(7). Clinical studies suggested that high levels of cytokines particularly IL- 6 , TNF- $\alpha$, IL- $1 \alpha$, and IL$1 \beta$ are seen in SARS- COVID-19with severe patients requiring $\operatorname{ICU}(8)$. There is paucity of studies on the interleukin profile in COVID-19positive patients. We aimed to determine the levels of cytokines namely, Interleukin-1 $\alpha$ (IL-1 $\alpha)$, Interleukin-1 $\beta$ (IL-1 $\beta)$, Interleukin-6 (IL-6), Tumor necrosis factor- $\alpha$ (TNF- $\alpha$ ) in serum and to correlate these cytokine markers with routinely done biochemical tests of liver function (AST, ALT, ALP), D-Dimer, LDH and C-reactive protein and ferritin in hospitalized COVID-19. We also aimed to compare the cytokine levels between mild, moderate, and severe COVID-19infection positive patients. 


\section{MATERIALS AND METHODS}

The cross-sectional study was conducted in the Department of Clinical Biochemistry at Father Muller Medical College Hospital and the Father Muller Research Centre. This study was approved by the Institutional Ethics. As the ethics committee granted us waiver of consent due to use of left-over samples in the lab for analysis of cytokines, Informed consent was not required. Fifty-three confirmed COVID-19 positive patients by RT-PCR who were admitted to the hospital during India's first wave were included in this research. Asymptomatic patients admitted to the hospital due to coronavirus infection were excluded Data of routinely done biochemical tests for managing COVID-19 positive patients (liver function tests, Ddimer, CRP, Ferritin, LDH) and the clinical history of disease severity-mild, moderate, severe; were collected from the database. Cytokines (IL-6, TNF- $\alpha$, IL- $\alpha$, IL-1 $\beta$ ) were assayed by Sandwich ELISA using ELISA kits of Diaclone and ELISA reader of Biorad. The procedure was followed as per the manufacture's instruction. Standards and control specimen were run along with samples in each batch of analysis.

\section{Ethical approval}

All procedures performed in studies involving human participants were as per the ethical standards of the institutional research committee and with the 1964 Helsinki declaration and its later amendments or comparable ethical standards. The study was approved by Father Muller Institutional ethics committee. (FMMC/CCM/538/2020)

\section{Statistical analysis}

Analysis was done using SPSS version 23.0 software. The descriptive statistics median and IQR, KruskalWallis test, Bonferroni test were used for the comparisons between groups. Pearson Correlation statistical test was used to assess the association between Cytokines (IL6, IL-1 $\alpha, 1 \beta$, TNF- $\alpha$ ) with AST, ALT, D-dimer, ferritin, CRP, LDH markers. Value of $\mathrm{P}<0.05$ was considered statistically significant.

\section{RESULTS}

Results of our study are presented in tables 1 to 3 . There was significant difference in serum levels of CRP, ferritin, LDH and IL-6 when the mild, moderate, and severe cases were compared. Serum CRP was significantly higher in moderate and severe cases of COVID-19when compared to mild cases. The serum CRP levels showed increase with progression of the disease. Similar observations were seen with regard to LDH, ferritin and IL-6 (Table 2). Among the cytokines IL-6 showed significant positive correlation with LDH, D-dimer and IL- $1 \alpha$ among the COVID19 patients; while serum IL- $1 \alpha$ showed significant positive correlation with LDH, D-dimer and TNFalpha (Table 3).

Table 1: IQR of IL 6, IL-1 $\alpha$, IL 1 $\beta$, and TNF- $\alpha$, AST, ALT, ALP, LDH, Ferritin, CRP.

\begin{tabular}{|c|c|c|c|}
\hline $\begin{array}{c}\text { Biochemical markers } \\
(\mathbf{n = 5 3})\end{array}$ & \multicolumn{3}{|c|}{ Percentile } \\
\cline { 2 - 4 } & $\mathbf{2 5}^{\text {th }}$ & $\mathbf{5 0}^{\text {th }}($ Median$)$ & $\mathbf{7 5}^{\text {th }}$ \\
\hline AST & 27.50 & 43.00 & 63.50 \\
\hline ALT & 19.00 & 33.00 & 55.00 \\
\hline ALP & 67.00 & 78.00 & 108.00 \\
\hline LDH & 233.50 & 331.00 & 441.00 \\
\hline D-DIMER & 324.50 & 522.00 & 1033.00 \\
\hline CRP & 14.6600 & 45.1000 & 111.910 \\
\hline Ferritin & 208.0000 & 410.1000 & 866.900 \\
\hline IL-6 & 6.350 & 21.700 & 74.300 \\
\hline TNF- $\boldsymbol{\alpha}$ & 15.450 & 17.900 & 21.350 \\
\hline IL-1 $\alpha$ & 70.23350 & 75.77100 & 106.690 \\
\hline IL-1 $\beta$ & 33.50200 & 35.49200 & 44.082 \\
\hline
\end{tabular}

Table 2: Difference between mild, moderate, and severe COVID-19infections with regard to various biomarkers (Kruskal Wallis test was done to find out the association between severity of COVID-19 infections with the biochemical markers)

\begin{tabular}{|c|c|c|c|c|}
\hline \multicolumn{2}{|c|}{ Group } & N & Median (IQR) & Kruskal Wallis test p value \\
\hline \multirow{3}{*}{ AST } & Mild & 18 & $43(20.75--56)$ & 0.086 \\
\cline { 2 - 4 } & Moderate & 21 & $36(26.5--57.5)$ & \multirow{2}{*}{0.132} \\
\cline { 2 - 4 } & Severe & 14 & $56.5(36.75--109)$ & \\
\hline \multirow{3}{*}{ ALT } & Mild & 18 & $32.5(16.75--58.5)$ & \multirow{2}{*}{0.808} \\
\cline { 2 - 4 } & Moderate & 21 & $27(15.5--45.5)$ & \\
\cline { 2 - 4 } & Severe & 14 & $48(24.25--58.25)$ & \\
\hline \multirow{3}{*}{ ALP } & Mild & 18 & $76.5(61.25-108)$ & \multirow{2}{*}{$0.001 * * *$} \\
\cline { 2 - 4 } & Moderate & 21 & $88(68--112)$ & \\
\cline { 2 - 4 } & Severe & 14 & $79(64.5--94.5)$ & \\
\hline
\end{tabular}




\begin{tabular}{|c|c|c|c|c|}
\hline & Severe & 14 & 504(343.5--832.25) & \\
\hline \multirow[t]{3}{*}{ D-Dimer } & Mild & 18 & $428.5(225--751)$ & \multirow[t]{3}{*}{0.054} \\
\hline & Moderate & 21 & $460(337.5--896)$ & \\
\hline & Severe & 14 & 915(397.25--3104.5) & \\
\hline \multirow[t]{3}{*}{ CRP } & Mild & 18 & $10.425(3.865--15.1425)$ & \multirow[t]{3}{*}{$0.000^{* * *}$} \\
\hline & Moderate & 21 & 45.29(41.095--72.185) & \\
\hline & Severe & 14 & $203.305(143.97--287.5825)$ & \\
\hline \multirow[t]{3}{*}{ Ferritin } & Mild & 18 & $254(187.275--577.775)$ & \multirow[t]{3}{*}{$0.003^{* * * *}$} \\
\hline & Moderate & 21 & $304.7(201.85--651.95)$ & \\
\hline & Severe & 14 & 976.5(423.9--1597.75) & \\
\hline \multirow[t]{3}{*}{ IL-6 } & Mild & 18 & $9.1(3.55--23.275)$ & \multirow[t]{3}{*}{$0.024 *$} \\
\hline & Moderate & 21 & 31(11.45--69.45) & \\
\hline & Severe & 14 & 118.6(3.675--191.3) & \\
\hline \multirow[t]{3}{*}{ TNF- $\alpha$} & Mild & 18 & $18.65(15.85--23.125)$ & \multirow[t]{3}{*}{0.167} \\
\hline & Moderate & 21 & $16.2(13.7--20.35)$ & \\
\hline & Severe & 14 & $18.7(16.875--25.625)$ & \\
\hline \multirow[t]{3}{*}{ IL-1a } & Mild & 18 & $71.57(65.36525--135.247)$ & \multirow[t]{3}{*}{0.365} \\
\hline & Moderate & 21 & 78(70.4375--92.79) & \\
\hline & Severe & 14 & 76.352(71.37775--129.69) & \\
\hline \multirow[t]{3}{*}{ IL-1 $\beta$} & Mild & 18 & $35.18(32.414--41.0535)$ & \multirow[t]{3}{*}{0.386} \\
\hline & Moderate & 21 & $35.492(33.9055--37.9765)$ & \\
\hline & Severe & 14 & $36.951(33.87475--67.782)$ & \\
\hline
\end{tabular}

$\mathrm{p}^{* * *}<0.001$ (very highly significant), $\mathrm{p}^{* *}<0.01$ (highly significant), $\mathrm{p}^{*}<0.05$ (significant).

Table 3: Correlation between various biomarkers in COVID-19 $(n=53)$

\begin{tabular}{|c|c|c|c|}
\hline \multicolumn{2}{|c|}{$\begin{array}{c}\text { Strength of association between the cytokine and } \\
\text { other markers }(n=53)\end{array}$} & \multirow{2}{*}{$\begin{array}{c}\text { r (Pearson Correlation) } \\
.416\end{array}$} & \multirow{2}{*}{$\begin{array}{c}\mathbf{P} \\
.002\end{array}$} \\
\hline Cytokines & IL-6\&LDH & & \\
\hline \& LDH & TNF- $\alpha \&$ LDH & .030 & .833 \\
\hline & IL-1 $\alpha \&$ LDH & -.066 & .637 \\
\hline & IL- $1 \beta \& \mathrm{LDH}$ & .303 & .027 \\
\hline \multirow{12}{*}{$\begin{array}{l}\text { Cytokines } \\
\text { \& AST, } \\
\text { ALT, ALP }\end{array}$} & IL-6 \& AST & .188 & .177 \\
\hline & TNF- $\alpha \&$ AST & .049 & .725 \\
\hline & IL-1 $\alpha \&$ AST & -.046 & .746 \\
\hline & IL-1 $\beta \&$ AST & -.101 & .472 \\
\hline & IL-6 \& ALT & .005 & .974 \\
\hline & TNF- $\alpha \&$ ALT & -.047 & .740 \\
\hline & IL-1 $\alpha \&$ ALT & .002 & .988 \\
\hline & IL-1 $\beta \&$ ALT & -.170 & .224 \\
\hline & IL-6 \& ALP & -.064 & .654 \\
\hline & TNF- $\alpha \&$ ALP & .191 & .179 \\
\hline & IL-1 $\alpha \&$ ALP & -.071 & .622 \\
\hline & IL-1 $\beta \&$ ALP & -.006 & .969 \\
\hline \multirow{4}{*}{$\begin{array}{c}\text { Cytokines } \\
\text { \& CRP }\end{array}$} & IL-6 \& CRP & .226 & .104 \\
\hline & TNF- $\alpha \&$ CRP & -.021 & .880 \\
\hline & IL-1 $\alpha \&$ CRP & -.058 & .679 \\
\hline & IL-1 $\beta \&$ CRP & .021 & .883 \\
\hline \multirow{4}{*}{$\begin{array}{l}\text { Cytokines } \\
\text { \& Ferritin }\end{array}$} & IL-6 \&Ferritin & .077 & .582 \\
\hline & TNF- $\alpha \&$ Ferritin & -.056 & .692 \\
\hline & IL-1 $\alpha$ \&Ferritin & -.107 & .444 \\
\hline & IL-1 $\alpha$ \&Ferritin & -.106 & .448 \\
\hline \multirow{4}{*}{$\begin{array}{l}\text { Cytokines } \\
\text { and D- } \\
\text { dimer }\end{array}$} & IL-6 \& D-Dimer & .350 & .010 \\
\hline & TNF- $\alpha \&$ D-Dimer & -.022 & .874 \\
\hline & IL-1 $\alpha \&$ D-Dimer & -.028 & .841 \\
\hline & IL-1 $\beta \&$ D-Dimer & .350 & .010 \\
\hline \multirow{6}{*}{ 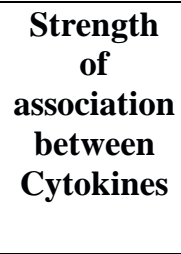 } & IL-6 \& TNF- $\alpha$ & -.020 & .886 \\
\hline & IL-6 \& IL-1 $\alpha$ & -.074 & .596 \\
\hline & IL-6 \& IL-1 $\beta$ & .303 & .027 \\
\hline & TNF- $\alpha \&$ IL- $1 \alpha$ & -.009 & .948 \\
\hline & TNF- $\alpha \&$ IL- $1 \beta$ & .561 & .000 \\
\hline & IL-1 $\alpha \&$ IL-1 $\beta$ & .079 & .574 \\
\hline
\end{tabular}




\section{DISCUSSION}

Our study showed significant difference with regard to the biochemical markers CRP, ferritin, LDH and IL-6 among mild, moderate, and severe COVID-19cases. There was significant correlation of IL- 6 and IL-1 $\beta$ with the conventionally used biomarkers LDH and Ddimer. The findings of various studies on cytokines in COVID-19 are summarized in table 4.

To evaluate the impact of SARS-Co V-2 on cytokine levels we evaluated IL-6, IL- $1 \alpha$, IL-1 $\beta$, and TNF- $\alpha$; we observed significant change in IL-6 but, other cytokines did not show any significant difference between the mild, moderate, and severe COVID-19 cases. However, the levels of all cytokines were significantly higher than the biological reference intervals reported with healthy population, in various studies, indicating cytokine storm(9). The increases in cytokines IL-6 is in concordance with the findings of previous studies. The change observed has been suggested to be due to the cytokine storm, inflammation and tissue injury.

The findings of IL- $1, \mathrm{IL}-1 \beta$ and TNF- $\alpha$ not differing as per severity of the disease is a salient finding of our study. Previously, Chen et al. reported higher levels of IL- 6 and TNF- $\alpha$ in severe cases of COVID-19 when compared to moderate cases and these authors also reported that levels of IL- $1 \beta$ did not differ between the severe and moderate cases (12). We assessed the correlation of cytokines with liver function marker enzymes, and the conventional COVID biomarkers $\mathrm{LDH}$, ferritin, D-dimer and CRP. We observed significant correlation of IL- 6 and IL- $1 \beta$ levels with LDH and D-dimer, and significant correlation between IL-1 $\beta$ with IL- 6 and TNF- $\alpha$. Previously, Effenberger et al., showed a significant association between liver markers and IL-6 $(14,15)$.

Table 4: Previous studies on cytokines and COVID-19

\begin{tabular}{|c|c|c|c|}
\hline Authors & $\begin{array}{l}\text { Sample size } n \\
\text { Type of study }\end{array}$ & Groups & Findings \\
\hline Han et al.,(14) & $\begin{array}{l}102 \text { COVID-19 } \\
\text { patients. } \\
\text { Longitudinal study }\end{array}$ & $\begin{array}{l}\text { Classified into } \\
\text { moderate, severe, and } \\
\text { critical. }\end{array}$ & $\begin{array}{l}\text { Higher serum levels of cytokines (TNF- } \alpha \text {, IFN- } \\
\gamma, \text { IL-2, IL- } 4 \text {, IL- } 6 \text {, and IL-10) and CRP than } \\
\text { control individuals. IL-10 positively correlated } \\
\text { with CRP levels }\end{array}$ \\
\hline Zeng et al., (10) & $\begin{array}{l}\text { 317laboratory- } \\
\text { confirmed COVID-19 } \\
\text { patients. } \\
\text { Retrospective study. }\end{array}$ & $\begin{array}{l}\text { Moderate, severe, or } \\
\text { critically ill form of } \\
\text { the disease }\end{array}$ & $\begin{array}{l}\text { Critically ill patients had higher concentrations } \\
\text { of soluble interleukin (IL)- } 2 \text { receptor, IL- } 6 \text {, IL- } \\
8, \mathrm{IL}-10, \mathrm{TNF}-\alpha \text {, ferritin, procalcitonin, LDH, } \\
\text { hsCRP, and hsCRP/L than patients with severe } \\
\text { or moderate disease }\end{array}$ \\
\hline Zhang et al., (16) & $\begin{array}{l}901 \text { patients with } \\
\text { SARS-CoV-2 } \\
\text { infection. } \\
\text { Cohort study }\end{array}$ & $\begin{array}{l}\text { COVID-19patients - } \\
\text { grouped as Common } \\
\text { cases, severe cases, } \\
\text { and critical cases. }\end{array}$ & $\begin{array}{c}\text { Significant difference in IL-6 levels between } \\
\text { common, severe, and critical groups. IL- } 6 \text { level } \\
\text { of }>37.65 \mathrm{pg} / \mathrm{ml} \text { was predictive of in-hospital } \\
\text { death with a } 91.7 \% \text { sensitivity and } 95.7 \% \\
\text { specificity. }\end{array}$ \\
\hline Chen et al., (12) & $\begin{array}{l}21 \text { patients COVID-19 } \\
\text { were analyzed. } \\
\text { Retrospective study }\end{array}$ & $\begin{array}{l}\text { Classified as severe } \\
\quad(11 \text { cases }) \text { and } \\
\text { moderate (10 cases })\end{array}$ & $\begin{array}{l}\text { Severe cases - had markedly higher levels of } \\
\text { IL-2R, IL-6, IL-10, and TNF- } \alpha \text {, when } \\
\text { compared to moderate cases. }\end{array}$ \\
\hline Del Valle et al.,(9) & $\begin{array}{c}\text { Cohort } \\
n=1715\end{array}$ & $\begin{array}{l}\text { Mild, moderate, } \\
\text { severe, and severe } \\
\text { with end-organ } \\
\text { damage }\end{array}$ & $\begin{array}{c}\text { High serum IL-6, IL- } 8 \text { and TNF- } \alpha \text { levels at the } \\
\text { time of hospitalization were strong and } \\
\text { independent predictors of patient survival } \\
\text { Elevated IL- } 6 \text { and TNF- } \alpha \text { serum levels at } \\
\text { presentation were strong predictors of disease } \\
\text { severity and survival, }\end{array}$ \\
\hline Keddie et al.,(13) & $\begin{array}{c}203 \text { samples } \\
\text { Cross-sectional } \\
\text { observational study }\end{array}$ & $\begin{array}{c}\text { WHO COVID-19 } \\
\text { ordinal severity scale }\end{array}$ & $\begin{array}{c}\text { IL-6, strongly correlated with the WHO ordinal } \\
\text { scale of illness severity. IL- } 6 \text { levels of } \geq 3.27 \\
\mathrm{pg} / \mathrm{ml} \text { provided a sensitivity of } 0.87 \text { and } \\
\text { specificity of } 0.64 \text { for a requirement of } \\
\text { ventilation }\end{array}$ \\
\hline $\begin{array}{l}\text { Effenberger } \text { et al., } \\
\text { (15) }\end{array}$ & $\begin{array}{l}655 \text { patients with } \\
\text { suspected COVID-19. } \\
\text { Cross-sectional design. }\end{array}$ & No groups made & Liver injury correlated with systemic IL-6 level \\
\hline
\end{tabular}

\section{CONCLUSION}

In conclusion, amongst the cytokines, IL-6 has consistently shown correlation with tissue injury marker LDH, disease severity marker D-dimer, and inflammatory marker IL-1 $\beta$. Other cytokine marker IL- $1 \beta$ has shown a significant correlation with TNF- $\alpha$, IL-6 and LDH. With the high levels of cytokines along with the biomarkers CRP, ferritin, LDH may be of importance to correlate with disease severity of SARS-CoV2.Assaying the profile of cytokines could be of immense value in diagnosis, prognosis, and management of COVID-19. Further studies with larger sample size correlating cytokines with disease severity and various other routine markers of COVID- 
19 are required to establish cytokines as reliable prognostic markers of COVID-19.

\section{ACKNOWLEDGEMENTS}

All the authors are thankful to the management of Father Muller Medical College for providing infrastructure and support. We acknowledge the funding support from Father Muller Research Centre.

\section{CONFLICT OF INTEREST}

Authors declare that there is no conflict of interest.

\section{REFERENCES}

1. Cai, Q., Huang, D., Yu, H., Zhu, Z., Xia, Z., Su, Y., et al., COVID-19: Abnormal liver function tests. J Hepatol. 2020 Sep 1; 73(3): 566-574.

2. Basu-Ray, I., Adeboye, A. S. M. Cardiac Manifestations Of Coronavirus (COVID-19). StatPearls. 2021 May 19; https://www.ncbi.nlm.nih.gov/books/NBK556152/

3. Feng, G., Zheng, K. I., Yan, Q. Q., Rios, R. S., Targher, G., Byrne, C. D., et al., Covid-19 and liver dysfunction: Current insights and emergent therapeutic strategies. J Clin Transl Hepatol. 2020; 8(1): 18-24.

4. Dinarello, C. A. Biologic Basis for Interleukin-1 in Disease. Blood. 1996 Mar 15; 87(6): 2095-2147.

5. Ye, Q., Wang, B. M. J. The pathogenesis and treatment of the 'Cytokine Storm' in COVID-19. J Infect. 2020 Jun 1; 80(6): 607-613. https://pubmed.ncbi.nlm.nih.gov/32283152/

6. Giemza-Stokłosa, J., Islam, M.A.K.P. Hyperferritinaemia: an iron sword of autoimmunity. Curr Pharm Des. 2019; 25(27): 2909-2918. https://pubmed.ncbi.nlm.nih.gov/31686632/

7. Feldmann, M., Maini, R. N., Woody, J. N., Holgate, S. T., Winter, G., Rowland, M., et al., Trials of anti-tumour necrosis factor therapy for COVID-19 are urgently needed. Lancet. 2020; 395(10234): 1407-1409.

8. Chen, L.Y.C., Hoiland, R. L., Stukas, S., Wellington, C. L., Sekhon, M. S. Confronting the controversy: Interleukin-6 and the COVID-19 cytokine storm syndrome. Eur Respir J. 2020; 56(4).

9. Del Valle, D. M., Kim-Schulze, S., Huang, H. H., Beckmann, N. D., Nirenberg, S., Wang, B., et al., An inflammatory cytokine signature predicts COVID-19 severity and survival. Nat Med. 2020 Aug 24; 26(10): 1636-1643. Available from: https://www.nature.com/articles/s41591-020-1051-9

10. Zeng, Z., Yu, H., Chen, H., Qi, W., Chen, L., Chen, G., et al., Longitudinal changes of inflammatory parameters and their correlation with disease severity and outcomes in patients with COVID-19 from Wuhan, China. Crit Care. 2020; 24(1): $1-12$.

11. Asghar, M. S., Kazmi, H.S.J., Khan, A. N., Akram, M., Hassan, M., Rasheed, U., et al., Poor Prognostic biochemical markers predicting fatalities caused by COVID-19: A retrospective observational study from a developing country. Cureus. 2(8): e9575. doi:10.7759/cureus.9575.

12. Chen, G., Wu, D., Guo, W., Cao, Y., Huang, D., Wang, H., et al., Clinical and immunological features of severe and moderate coronavirus disease 2019. J Clin Invest. 2020 May 1; 130(5): 2620-2629.

13. Keddie, S., Ziff, O., Chou, M. K., Taylor, R. L., Heslegrave, A., Garr, E., et al.,Laboratory biomarkers associated with COVID-19 severity and management. Clin Immunol. 2020 Dec; 221: 108614. doi: 10.1016/j.clim.2020.108614.

14. Han, H., Ma, Q., Li, C., Liu, R., Zhao, L., Wang, W., et al., Profiling serum cytokines in COVID-19 patients reveals IL6 and IL-10 are disease severity predictors. Emerg Microbes Infect. 2020; Jan; 9(1): 1123-1130.

15. Effenberger, M., Grander, C., Grabherr, F., Griesmacher, A., Ploner, T., Hartig, F., et al., Systemic inflammation as fuel for acute liver injury in COVID-19. Dig Liver Dis [Internet]. 2021; 53(2): 158-165.
16. Zhang, J., Hao, Y., Ou, W., Ming, F., Liang, G., Qian, Y., et al., Serum interleukin-6 is an indicator for severity in 901 patients with SARS-CoV-2 infection: a cohort study. J Transl Med [Internet]. 2020 Dec 1 [cited 2021 Jul 29]; 18(1). Available from: https://pubmed.ncbi.nlm.nih.gov/33121497/ 